\title{
Emergence of Project Based Learning in Professional Education
}

\author{
${ }^{1}$ Dr. Sunil Kumari \& ${ }^{2}$ Dr. Sanjay Nandal \\ ${ }^{1}$ Rohtak, Haryana, India. \\ ${ }^{2}$ Assistant Professor at IMSAR, MDU Rohtak, Haryana, India.
}

(c) Scholedge International Journal of Multidisciplinary \& Allied Studies (ISSN 2394-336X), Vol.03, Issue 10 (2016) pg208-214. Published by: Scholedge R\&D Center [http://www.thescholedge.org/journals/] [Email: editorial@thescholedge.org]

\begin{abstract}
Purpose: Present study aims at measuring the effectiveness of Project Based learning in professional education especially in MBA Program.

Methodology: A sample of 100 participants has been taken in two groups- control and experimental. Pre-post analysis of control and experimental group has been done to know the significance of difference between both groups. Validity of results has been tested with $\mathrm{t}$-values.

Findings: Study reveals that PBL enhances the professional skills in the students. The comparative value of scores found the $t$-values significant at 0.01 level which validated the results of the study. It is concluded that the project-based learning method can yield a surplus value compared to more traditional types of education and training.

Implications: Present study would benefit to regulatory bodies and professional institutes to permit the PBL in their professional courses. It would also ease the companies to find the trained people. Society would also benefit by getting early employment, more jobs, more output, more growth etc.
\end{abstract}

Originality of value: Study is original and exclusive in nature which proves a milestone at this stage of transformation of business and educational world.

Key Words: PBL, Professional Education, Skills, MBA Program.

\section{Introduction}

We are living in a world of change where change is being witnessed in every sphere. Such change is also attacking on our educational systems where modern and innovative techniques are replacing the traditional and old ones. Corporate world seems in search of people versed of not only theoretical knowledge but also skilled in practical application thereof. to meet the this kind of requirement of companies, now educational and training institutes have changed their teaching and learning methods and techniques, particularly in professional education. They have started to focus on the application based studies. In the field of professional education, the course of Master of Business Administration (MBA) has been criticized for laying emphasis on too much theory and impenetrable research that has small to do with the actual business arena. Thus, project based learning in MBA Program, has been acknowledged as solution to this problem recently. Being the subject new one; it lacks the literature availability thereon that initiates the researcher to make the study on this topic.

Now the question arises what the Project Based Learning (PBL) is? Project-Based Learning (PBL) is an individual or group activity that goes on over a period of time, resulting in a product, 
presentation, or performance. It is now used at many professional institutes to promote lifelong learning, open inquiry, teamwork, and critical thinking. Traditional learning is being replaced by $\mathrm{PBL}$ which is new and innovative educational technique.PBL is realistic execution of what we learn academically [Emily Pilloton, Author of Design Revolution \& TED Speaker]. PBL is learning technique under which learner learns the not only theoretically but by solving the problems at work place. It goes beyond the classroom based teaching and training. It focuses on practical implications of the theoretical interpretations of the knowledge [George Lucas, Hollywood Director \& Chairman of The George Lucas Educational Foundation] Learning is associated with the projects where students are involved in solving the problems, making the decisions and executing their knowledge in practical form. Students investigate the things in working environment and explore some new insights there from by producing some realistic outputs and thought processes over a period of time. Faculty member acts as a facilitator who designs the appropriate and realistic cases for each group of students as per their thrust areas. Educator permits the learners to analyze the work given to them in their own way which provides a scope to students to understand the things and discover some new things. Gradually, the students turn to a facilitator themselves as they grow to be efficient self-directed learners. Thus, project based learning has become the demand of changing scenario that seeks to be incorporated in the educational systems. "While technical and scientific techniques within management disciplines are vital, the functional implications of knowledge of management as well as an recognition of its skill and expertise should be improved in MBA Programs"( Henry Mintzberg). Most of the companies look for talent which can not only think and repeat the theories but can also resolve the problems by finding new ways which needs experimental learning instead of proving the theoretical knowledge [Andrew Allen, Director of Illinois Business Consulting (IBC) at the University of Indiana Urbana-Champaign].

\section{Literature Review}

Karen A. Cole (1999) found the project based learning model an effective means of professional development of students. Study revealed that partnership of theory and practical applications build the technogical and pedagogical advancements.

J. B. Arbaugh (2000) focused on internet based MBA learning. Study was made to examine the impact of technology, innovations, pedagogy and students personal characteristics on MBA course learning through internet. It was found that only instructor's efforts makes the classroom environment participative and interactive that makes learning easy and creative, so relationship between teacher's students oriented skills and student's learning. Other features associated with the MBA Program package like easy use of software package, flexible classroom environment and time allowed to students to be logged into etc neither were nor found significant.

Janjua Fauzia (2013) made a study titled "Project Based Learning in Business English Classroom". An experiment on a class of forty students of MBA program dividing the class into two groupscontrol (without PBL) and experimental (with PBL), was made to diagnose the effectiveness of MBA being associated to the business projects. Communication skills were tested of both groups. Pre-post analysis found the t-values significant which confirmed that project based MBA improved the business communication skills.

Vanessa Vega (2015) reviewed the researches made on project based learning and found that Most of the studies proved that PBL increases the content retention, makes the positive attitude of students towards learning, and enhances the sense of outcomes. Being the PBL evidence based study, it is recommended to be incorporated in all courses particularly in professional programs.

So many studies have been made on project based learning to identify the effectiveness of PBL in modern changing world of technology and innovations but there is severe lack of studies on 
project based learning with reference to MBA Program, which initiates the researchers to choose this topic for the purpose of study.

\section{Objectives of the Study}

- To explain the concept and importance of Project Based Learning (PBL).

- To investigate the effectiveness of PBL in professional education especially in MBA Program.

\section{Research Methodology}

It contains following procedures:

- Research Design: Being the study exploratory in nature, it has been go through collection of data from past participants (Control group) and current participants (Experimental group) of MBA without Boundaries (MBAWB) program and analyzing the same using the mean, standard deviation and t-test etc.

- Data Collection: Both types of data i.e. primary as well secondary have been used. Qualitative data was collected through interviews, both face-to- face and in the form of electronic mail. Scores have been assigned to subjective content on the basis of rating.

- Sampling Unit: The participants are students enrolled in the MBA program. Two sample have been taken one of past participants (control group) who passed MBA not being the part of projects and other one of current participants (experimental group) who are associated with projects of companies.

- Research Method: Research is based on sampling not census method.

- Sample Size: Following two samples were taken:

1. Control group: 100

2. Experimental group: 100

- Sampling Type: Sampling is deliberated/ purposive in nature.

- Analyzing Tools: T-test has been used to know the significance of difference between scores of control group and experimental group on which basis level of effectiveness of PBL has been measured.

- Parameters of the Study: Seven Following aspects of professional development have been taken into account to measure the effectiveness of project based learning in MBA program:

1) Collaborative Skills: when people work or learn together, they are expected to have the sense belongingness, sharing, trust and respect to others. This is the first thing study has diagnosed whether collaborative skill have been developed during the project based learning environment.

2) Technical Skills: A technical skill refers to ability to execute the theoretical knowledge in practical form in innovative manners.

3) Strategic Thinking: Strategic thinking involves comprehensive view of an aspect linking it with entirety.

4) Problem Solving Ability: how fast the learners resolve the problems given to them.

5) Leadership Skills: Leadership skills are nothing but the power to influence the others.

6) Research Attitude: research attitude shows how keen the learners are to make innovations and technological developments.

7) Self Learning: Whether learning induce the students to explore the more knowledge itself.

- Hypotheses: Being the seven variables or parameters of the study, null hypotheses have been set in regard of these variables as below: 
H1: Project based learning doesn't improve the collaborative skills.

H2: Project based learning doesn't develop the Technical Skills.

H3: Project based learning doesn't increase the Strategic Thinking.

$\mathrm{H}_{4}$ : Project based learning doesn't enhance the Problem Solving Ability.

H5: Project based learning doesn't create the Leadership Skills.

H6: Project based learning doesn't raise the Research Attitude.

$\mathrm{H7}$ : Project based learning doesn't lead to e Self Learning.

\section{Results \& discussions}

Being the qualitative investigation, scores were gathered through the interviews to capture students' perceptions and views regarding the effectiveness and usefulness of project based action learning approach. Additional discussions with faculty members were combined, and then compared with the participants' feedback in order to understand the extent of the outcomes. Data in the form of narrative and participant interview transcripts in term of scores at quality rating scale were analyzed and reported using differential analysis. The interviews focused on the skills gained by the student in certain business areas given in table1.

Table 1: Statistical Analysis of Data gathered

\begin{tabular}{|l|l|l|l|l|l|l|}
\hline S. No. & Parameters of Skills & \multicolumn{2}{l}{$\begin{array}{l}\text { Control Group } \\
\text { Average Scores }\end{array}$} & $\begin{array}{l}\text { Experimental Group } \\
\text { Average Score }\end{array}$ & \\
& & & & \\
& & & & \\
& & Mean & SD & Mean & SD & t- value \\
\hline $\mathbf{1 .}$ & Collaborative Skills & 19.16 & 3.64 & 25.84 & 4.96 & $16.21^{*}$ \\
\hline $\mathbf{2 .}$ & Technical Skills & 6.19 & 1.61 & 9.84 & 1.42 & $25.42^{*}$ \\
\hline $\mathbf{3 .}$ & Strategic Thinking & 96.89 & 2.85 & 99.35 & 2.11 & $6.937^{*}$ \\
\hline $\mathbf{4 .}$ & Problem solving Ability & 12.98 & 2.12 & 13.89 & 1.94 & $3.17^{*}$ \\
\hline $\mathbf{5 .}$ & Leadership Skills & 7.32 & 1.93 & 7.98 & 1.76 & $2.92^{*}$ \\
\hline $\mathbf{6 .}$ & Research Attitude & 55.67 & 11.76 & 64.93 & 10.92 & $7.49^{*}$ \\
\hline $\mathbf{7 .}$ & Self Learning & 10.45 & 1.95 & 13.65 & 1.71 & $19.23^{*}$ \\
\hline Note: All * t-values are significant at 0.01 levels. & & & & \\
\hline
\end{tabular}

Study rejects the H1: Project based learning doesn't improve the collaborative skills because table 1 shows mean score 19.16 of control group whereas it has increased to 25.84 of experimental group and such difference is significant in terms of t-value i.e. 16.21 at $1 \%$ level. Study also rejects the H2: Project based learning doesn't develop the Technical Skills. Because mean scores of control group are 6.19 where it is 9.84 of experimental group with the highest $t$-value i.e. 25.42 that indicates that project based learning improves the technical skills more in comparison to other skills. It can be said that technical ability is more prominent to PBL. Same kinds of results have been traced in rest of the variables and hypotheses. Results reveal that average scores of all variables (that are the parameters of skills) of experimental group are higher than control group which indicates the positive change in skill development because of PBL applied in MBA Program. Difference in average scores of both groups is also significant which has been measured in terms of t-values. Thus study rejects all hypotheses i.e. $\mathrm{H}_{1}, \mathrm{H}_{2}, \mathrm{H}_{3}, \mathrm{H}_{4}, \mathrm{H}_{5}, \mathrm{H}_{6}$ and $\mathrm{H}_{7}$ and confirms the significant positive change in skills and abilities of the learners due to adoption of project based learning but leadership skills have the least $t$-value that shows that PBL develops the leadership skills but in comparison to other skills it is least whereas it is highest in case of technical skills. it can be interpreted that technical sense needs application of theoretical knowledge in work environment, so it can be much uplifted with the help of PBL whereas leadership skills get flourished much more in position and power and responsibility in real sense 
in comparison to part time projects. Team \& group spirits arise in PBL which is also a part of leadership but complete leaders can be made only in real and full time jobs.

Although skills development is subjective in nature, participants generally indicated that the program has greatly improved their leadership, research, analytical/strategic thinking, creative and technical skills, particularly computers and other technology-based, e.g. computerized spreadsheets and Internet search. Some participants who came to the program without any significant knowledge or skills in information technology felt that mastering information technology prior to joining the program could save them from spending the extra time learning the skill during the project. All participants agreed that their ability to integrate information from a wide variety of sources and skills in financial analysis, business modeling, collaboration \& working in teams, working with ambiguity, and selling ideas \& marketing have significantly improved.

\section{Conclusions}

Study reveals that project-based learning $(\mathrm{PBL})$ in professional education especially in $\mathrm{MBA}$ Program generally enhances student analytical, inter-personal, leadership, technical and collaborative skills. In general, participants agreed that PBL greatly contributed to the students' business knowledge and research aptitude. However, it is not clear if some professional skills that the students have are indeed due to MBAWB, considering that many of the participants are highly experienced and/or have been working for several years. Concerns raised include the thrust for more instruction in the area of financial management and accounting, extra instruction time and workshops that are driven towards certain projects during residency weeks, and supporting material such as online tutorials and links to useful resources on the subject. In terms of online collaboration and communication, there is a need for more faculty member's feedback and direction during a project. One specific suggestion was to hold a class wide NetMeeting session during the first few projects to ensure everyone is comfortable with the learning mechanisms and goals. As a final point, MBAWB program needs to be marketed more actively and nationally to enhance its reputation in particular and the reputation of the university in general. This research has been conducted for MBA program; therefore, caution is warranted in generalizing its results to other professions. Project-based learning is a proven educational technique, but working environments exercised in MBA may not necessarily applicable to other professions elsewhere. Nevertheless, the results of this study suggest the potential of PBAL, when used in MBA professional education, to enhance students' technical and analytical abilities. The use of modern communication tools gives PBL greater potential and the advantage to work even more successfully.

\section{Implications of the Study}

Present study would prove a milestone in designing the courses and patterns of professional education specifically the MBA program which seems in high demand in this stage of transformation of business as well as educational world. As study provides the strong evidences of being the project based learning in professional education effective, it would benefit the various stakeholders i.e. educationists, educational \& professional educational institutions, corporate world and learners. It will also strike the minds of education providers to rethink upon the traditional methods being used presently in professional education. Study also gives a subject matter to research scholars to look into, where there is severe shortage of literature on this topic. It will also be helpful to students to inculcate their abilities and skill in realistic working environment so that skills can be generated instead of mere theoretical knowledge. Companies will also get the benefit of this study as they would be able to find the competent and skilled workforce that will reduce the time and cost of training to newly hired employees. Newly 
appointed employees can be now placed direct on job. Study will give its concrete contribution in social and economic development. It will benefit the society at large by generating employment opportunities at global level, increasing the per capita income and growth rate etc.

\section{Recommendations}

Study makes the following recommendations:

- All regulatory bodies of professional education should permit the professional and educational institutions to design their professional programs or courses based on projects. They should also rank and accredit the top \& advanced grades to professional and training institutions adopting PBL.

- All professional institutions should incorporate the project based learning in their courses and programs. It is recommended to replace the traditional methods of teaching based on only theoretical knowledge, with project based learning techniques.

- Companies should change their business policy. They should also tie-up with professional educational and training centers to conduct the joint projects in collaborations with.

\section{Limitations of the study}

- Being study based on primary data, it attributes the all limitations of primary data collection, coding and analysis etc.

- Furthermore data used is qualitative in nature that may offer some variations in proper rating and subjective judgments.

- Sample size, time and cost constraints may limit the universalisation of the results of the study.

- Control group has been compared with the experimental group which may basically diverse in nature to each other.

\section{References}

- Arbaugh, J. B. (2000). How Classroom Environment and Student Engagement Affect Learning in Internet-based MBA Courses. Business Communication Quarterly, 63(4), 9-26.

- Carvalho, G. C., Kirch, D. P. (1996). A Problem-Based MBA Curriculum: the Ohio University experience, Mid-American Journal of Business, 11(2), 9-18.

- Dellana, S., Collins, W., West, D. (2000). On-Line education in a Management Science Course-Effectiveness and Performance Factors. Journal of Education for Business, 75(5), 43-47.

- Dick, B. (1997). Action learning and action research [Online]. Available at http://www.scu.edu.au/schools/gcm/ar/arp/actlearn.html

- Duin, A. H. (1998). The culture of distance education: Implementing an online graduate level course in audience analysis. Technical Communication Quartely, 7(4), 365-389.

- Elsaid, H. H., Schermerhorn, J. R. (1989) The Future of Higher Education for Business and Management, Mid-American Journal of Business, 6(2), 11-18.

- Girion, J. (2001) E-Learning and the MBA, eLearning [online], Available at: http://www.elearningmag.com/issues/june01/onlinemba.asp

- Janjua Fauzia (2013). Project-based Learning in Business English Classroom. Language in India, Jan2013, Vol. 13 Issue 1, p38-47. 10p. 2 Charts. Available at http://web.a.ebscohost.com/abstract?direct=true\&profile=ehost\&scope=site\&authtype=c rawler\&jrnl=19302940\&AN=88455815\&h=LqjNJoPWqt\%2bCoWujmyRD7MzQdoOozoP8G3 clcAkec7TDl2SLSJpf\%2boGmEDgkj8vRubzAd7HXMCKnASZNTSu5FQ\%3d\%3d\&crl=f\&crawll oc=cf\%3az\%2f0506578651\&crawllib=RD201301.LIB\&resultNs=AdminWebAuth\&resultLocal 
$=$ =ErrCrINotAuth\&crlhashurl=login.aspx\%3fdirect\%3dtrue\%26profile\%3dehost\%26scope\%3dsi te\%26authtype\%3dcrawler\%26jrnl\%3d19302940\%26AN\%3d88455815

- Vanessa Vega (2015). Project-Based Learning Research Review. Edutopia. Retrieved from http://www.edutopia.org/pbl-research-learning-outcomes

- Innovating MBA Curriculum with Project-Based Learning at http://www.edusourced.com/2015/08/06/innovating-mba-curriculum-with-project-basedlearning/

- Problem Based Learning. Retrieved from http://online.sfsu.edu/rpurser/ revised/pages/problem.htm

- Research Spotlight on Project-Based Learning. Retrieved from http://www.nea.org/tools/16963.htm

- The Value of Project-Based Learning for MBAs. Retrieved from http://www.edusourced.com/2015/06/12/the-value-of-project-based-learning-for-mbas/

\section{Acknowledgements}

I (Dr. Sanjay Nandal) acknowledge the support of my family, collogues, and close friends who initiated me to make this research work.

I (Dr. Sunil Kumari) am highly indebted to my mentor Dr Sanjay Nandal for his tutelage and commendable advices to me regarding this research work. To my late daughter JIYA, I dedicate this paper.

\section{Authors' Biographies}

Dr. Sunil Kumari: Author is M Com, M Phil, UGC NET Qualified and Doctorate in Finance as well as CFA with a wide experience of corporate and teaching. Furthermore she has presented many research papers in national and international seminars/ conferences and got her 45 papers published as well in national and international journals. She has also won four times Best Paper Award in national seminars.

Dr Sanjay Nandal: Author is working in main campus of MD University. He has contributed in many journals, conferences \& seminars of national and international level. He has also organized so many seminars, conferences and workshops at IMSAR. Since a long time he has also been associated with academia world by giving his concrete contribution in many kinds. 